\title{
Z BADAŃ CZWARTORZĘDU W POLSCE. PAMIECCI PROFESOR HALINY KLATKOWEJ
}

W 2017 roku mija 20 lat od śmierci Profesor Haliny Klatkowej - geografa i geomorfologa, przez całe zawodowe życie związanej z łódzkim ośrodkiem geograficznym. Acta Geographica Lodziensia to szczególne miejsce uczczenia Jej pamięci, ponieważ od pierwszego numeru pełniła obowiązki sekretarza redakcji, zaś w latach 19761997 była redaktorem, przez co miała znaczący wpływ na kształtowanie profilu tematycznego pisma. Oddajemy 106 tom czasopisma, na którego zawartość składa się 16 artykułów dotyczących zagadnień z zakresu geomorfologii i geologii czwartorzędu, prezentujących badania prowadzone obecnie w różnych częściach Polski. Tematyka artykułów bądź nawiązuje wprost do wątków badawczych Profesor Haliny Klatkowej, bądź wiąże się z nimi przez wspólną problematykę, a także metodykę i obszary badań.

Jedna z najważniejszych prac, jaka powstała w początkowym okresie kariery naukowej Pani Profesor, dotyczyła niecek i dolin denudacyjnych (Klatkowa 1965). Bezpośrednio do tego zagadnienia nawiązuje artykuł Twardego (2017), przedstawiający rozwój tych ważnych, stokowych form peryglacjalnych w holocenie.

Problematyka rozwoju rzeźby gór polskich, ze szczególnym naciskiem na określenie przeobrażenia stoków, została poruszona w pracach Starkla (2017) i Migonia (2017). Badania prowadzone w ostatnim czasie w Sudetach pozwoliły Migoniowi (2017) omówić wachlarz zachodzących tam procesów stokowych oraz wskazać holocen jako główny okres ich aktywności. Z kolei Starkel (2017) zwraca uwagę na poligeniczność rzeźby Karpat, podkreślając wieloetapowość przekształceń w zmiennych warunkach klimatycznych.

Peryglacjalne oraz holoceńskie przeobrażenia rzeźby obrzeżenia Gór Świętokrzyskich były przedmiotem pierwszych samodzielnych badań Klatkowej $(1955,1958)$. Do problemu roli soliflukcji $\mathrm{w}$ formowaniu teras dolinnych nawiązują autorzy artykułu prezentującego litologię i wiek osadów doliny Kamionki (Kalicki i in. 2017). Badania skoncentrowano na wyższej terasie, ukształtowanej u schyłku zimnego piętra warty, przemodelowanej $\mathrm{w}$ warunkach klimatu peryglacjalnego i nadbudowanej osadami eolicznymi.
W Kotlinie Sandomierskiej, w dolinie Wiszni, analizowane były vistuliańskie utwory rzeczne, a także przykrywające je osady eoliczne (Gębica $i$ in. 2017). Autorzy zastosowali szeroki zakres metod badawczych dla określenia litologii osadów i ich wieku bezwzględnego. Dokonali także oceny przydatności badanego obszaru terasy nadzalewowej i wieńczącej ją wydmy dla lokalizacji osadnictwa kultury łużyckiej i z okresu wczesnego średniowiecza.

Problematykę transportu, akumulacji i postsedymentacyjnych zmian cech osadów lessowych porusza artykuł Skurzyńskiego i in. (2017). Dzięki porównaniu dwu kilkunastumetrowych profili lessowych z Grzędy Sokalskiej i Przedgórza Sudeckiego wykazano wpływ warunków klimatycznych na cechy litologiczne i geochemiczne lessów oraz zachodzące $\mathrm{w}$ nich procesy glebotwórcze.

Zagłębienia bezodpływowe, ich geneza i charakterystyka wypełnień, stanowiły bardzo ważny wątek prac naukowych Pani Profesor (m.in. Klatkowa 1989, 1990). Wykazana przydatność badań tych form do wnioskowania paleogeograficznego, podsumowana w zredagowanym przez Klatkową (1990) 61 tomie Acta Geographica Lodziensia pt. „Kopalne zbiorniki z florą eemską w środkowej Polsce" stała się zachętą do podejmowania prowadzonych obecnie badań interdyscyplinarnych. Publikowane w niniejszym zeszycie artykuły Forysiaka i in. (2017), Kołodyńskiej-Gawrysiak (2017) oraz Majewskiego (2017) potwierdzają, że zagłębienia bezodpływowe stanowią świetne, naturalne ,pułapki sedymentacyjne”, a wypełniające je serie są dobrym źródłem materiału badawczego. W artykule Kołodyńskiej-Gawrysiak (2017) przedstawiona została istota tych form w obszarach lessowych Wyżyny Lubelskiej, opisano genezę zagłębień i zróżnicowanie osadów, oceniono także ich rolę w krajobrazie lessowym. Artykuł Forysiaka i in. (2017) traktuje o eemskovistuliańskich wypełnieniach kopalnych zagłębień bezodpływowych Wysoczyzny Łódzkiej. Jednak tematem przewodnim nie jest stratygrafia czy obraz paleogeograficzny, ale cechy litologiczne osadów wypełniających kopalne misy wykształcone w warciańskich utworach glacjalnych i flu- 
wioglacjalnych. Autorzy wskazują możliwość zastosowania podstawowej charakterystyki litologicznej osadów jako narzędzia do identyfikacji etapów wypełniania zagłębień. Dwa małe zagłębienia bezodpływowe położone na jednym $\mathrm{z}$ sandrów Pojezierza Zachodniopomorskiego i wypełniające je deluwia posłużyły Majewskiemu (2017) do analizy oraz szczegółowej charakterystyki litologicznej osadów stokowych.

Poza zainteresowaniami morfogenezą i cechami litologicznymi osadów ważne miejsce w pracach badawczych Profesor Klatkowej zajmowały zagadnienia stratygraficzne (Klatkowa 1972, 1979, 1990, 1993, 1994, 1995), a ich pogłębianiu służyły badania osadów biogenicznych, we współpracy z szerokim gronem paleobotaników i specjalistów z zakresu geochronometrii. Artykuł Dzieduszyńskiej (2017) wskazuje na przydatność datowań radiowęglowych nie tylko dla określania wieku badanych utworów, ale także, dzięki odpowiedniej obróbce statystycznej, do dyskutowania schematu stratygraficznego vistulianu. Autorka na podstawie dużego zbioru dat $\mathrm{z}$ obszaru środkowej Polski zaproponowała chronostratygrafię schyłku vistulianu i wykazała możliwość porównywania go ze schematami opartymi na badaniach high resolution.

Umieszczone w tomie dwa artykuły dotyczące zagadnień palinologicznych są właściwą ilustracją znaczenia tego rodzaju analiz w badaniach podejmowanych przez Profesor Halinę Klatkową (por. Klatkowa 1972, 1990). Balwierz (2017) prezentuje historię badań palinologicznych w łódzkim ośrodku geograficznym, w której duże znaczenie ma udział Pani Profesor w terenowym rozpoznawaniu stanowisk z osadami biogenicznymi i pozyskaniu profili do analiz. Wyniki badań, których częściami składowymi były analizy palinologiczne, Pani Profesor publikowała zazwyczaj we współautorstwie ze specjalistkami z ośrodka łódzkiego Zofią Balwierz i Marią Jastrzębską-Mamełką, ale podejmowała współpracę również z innymi palinologami (np. Klatkowa, Winter 1990). Zagadnienie palinokompleksu południowopolskiego, jakie przedstawiła $\mathrm{w}$ niniejszym tomie Winter (2017), jest ważnym wkładem autorki w problematykę stratygrafii środkowego plejstocenu Polski. Zaprezentowane trzy różne sukcesje interglacjalne stanowią podstawę dla wniosków paleoklimatycznych i stratygraficznych.

W badaniach utworów glacjalnych, jak też fluwioglacjalnych oraz osadów akumulowanych w środowisku peryglacjalnym Profesor Klatkowa stosowała szereg metod litologicznych, służących do dokumentowania ich cech strukturalnych i teksturalnych (Klatkowa 1972, 1982, 1989, 1993, 1996). W pracy Rdzanego i Frydrych (2017) autorzy stwierdzają, że litotypy osadów glacigenicznych wykazują powiązania zarówno z określonymi rodzajami środowisk sedymentacyjnych, jak i grupami genetycznymi form rzeźby, a profile litofacjalne i litogenetycznne mogą mieć zastosowanie dla rozpoznania osadów stref marginalnych lądolodów. W jednych z ostatnich publikacji Klatkowej (1996, 1999) poruszana była tematyka zaburzeń glacitektonicznych w osadach z okolic Łodzi, generowanych przez dynamiczne lub statyczne ciała lodowe. W utworach czwartorzędowych spotykane są także zaburzenia natury tektonicznej. Przegląd metod badawczych i sposobów identyfikacji sejsmitów poruszają Belzyt i Pisarska-Jamroży (2017). Przedstawione kryteria rozpoznawcze tego typu deformacji mogą posłużyć do poprawnego określania ich genezy.

W badaniach nad stratygrafią glin zwałowych w środkowej Polsce, prowadzonych w latach osiemdziesiątych i dziewięćdziesiątych Profesor Klatkowa (Klatkowa 1993) na szeroką skalę stosowała analizy petrograficzne. Badania dotyczyły frakcji żwirowej, choć Autorka wyrażała przekonanie o większej wartości stratygraficznej analizy materiału grubofrakcyjnego (otoczaki). Artykuł Tylmana i in. (2017) ukazuje przydatność dużych głazów narzutowych do określania wieku ich złożenia w czasie recesji lądolodu. Przedstawiane dane odnoszą się do datowania wieku ekspozycji głazów Pomorza metodą ziemskich izotopów kosmogenicznych i przydatności metody do ustalania chronologii ostatniego zlodowacenia.

Dolina Warty i Kotlina Kolska zostały stosunkowo późno objęte badaniami przez Profesor Klatkową (Klatkowa 1991). Problematyka glacjalna i fluwialna tego obszaru okazała się na tyle interesująca, że stanowiska znajdujące w odkrywce „Smulsko” kopalni węgla brunatnego „Adamów" zostały zaprezentowane przez Panią Profesor w 1994 roku na międzynarodowej konferencji INQUA SEQS Symposium "The Cold Warta Stage: lithology, paleogeography, stratigraphy" (Klatkowa 1994, 1995). Następnie badania zostały podjęte w sąsiedniej odkrywce „Koźmin” (Klatkowa i in. 1996). Bezpośrednio do tej części Kotliny Kolskiej nawiązuje artykuł Liska i Petery-Zganiacz (2017) prezentujący wyniki analiz vistuliańskich aluwiów Warty, zbadanych w rozległych odkrywkach „Koźmin Północ” i „Koźmin Południe” kopalni węgla brunatnego „Adamów”, położonych niemal w osi doliny dużej rzeki nizinnej. 
Od śmierci Pani Profesor upłynęło dwadzieścia lat. Z jednej strony to niewiele, bo stale pozostaje Ona w serdecznej pamięci kolegów, koleżanek oraz uczniów i współpracowników. Z drugiej - to długi okres, w którym nastąpił istotny postęp wiedzy związany z rozwojem metod badawczych. Artykuły zebrane w niniejszej publikacji dotyczą problematyki, którą interesowała się Profesor Halina Klatkowa, dlatego redakcja wyraża przekonanie, że z zainteresowaniem przyjęłaby ich treść.

Balwierz Z. 2017. Badania palinologiczne w regionie łódzkim. Acta Geographica Lodziensia 106: 129-138.

Belzyt S., Pisarska-Jamroży M. 2017. W jaki sposób badać sejsmity? Przegląd metod badawczych. Acta Geographica Lodziensia 106: 171-180.

Dzieduszyńska D. 2017. Przydatność zbioru dat radiowęglowych do rekonstrukcji zmian w środowisku schyłku vistulianu Polski Środkowej. Acta Geographica Lodziensia 106: 117-127.

Forysiak J., Majecka A., Marks L., Tołoczko-Pasek A., Okupny D. 2017. Cechy litologiczne wypełnień wybranych zagłębień bezodpływowych obszaru Wzniesień Łódzkich. Acta Geographica Lodziensia 106: 195-201.

Gębica P., Superson S., Trybała-Zawiślak K., Woronko B. 2017. Litologia, geneza i wiek osadów w Kalnikowie i Chotyńcu na Płaskowyżu Tarnogrodzkim (Kotlina Sandomierska). Acta Geographica Lodziensia 106: 65-86.

Kalicki T., Przepióra P., Podrzycki Ł. 2017. Budowa i wiek wyższej terasy Kamionki na odcinku Suchedniów-Rejów. Acta Geographica Lodziensia 106: 53-64.

Kołodyńska-Gawrysiak R. 2017. Zagłębienia bezodpływowe obszarów lessowych Polski. Stan i perspektywy badań. Acta Geographica Lodziensia 106: 105-116.

Lisek M., Petera-Zganiacz J. 2017. Cechy uziarnienia vistuliańskich aluwiów w dolinie Warty, Kotlina Kolska. Acta Geographica Lodziensia 106: 225-241.

Majewski M. 2017. Cechy uziarnienia deluwiów na tle osadów źródłowych na przykładzie zagłębień bezodpływowych w rejonie Łupawska (Pojezierze Zachodniopomorskie). Acta Geographica Lodziensia 106: 211-223.

Migoń P. 2017. Stoki sudeckie piętra leśnego w holocenie. Acta Geographica Lodziensia 106: 3752.
Rdzany Z., Frydrych M. 2017. Znaczenie metod litologicznych w rekonstrukcjach procesów glacigenicznych na przykładach z obszaru staroglacjalnego Polski Środkowej. Acta Geographica Lodziensia 106: 155-170.

Skurzyński J., Jary Z., Raczyk J., Moska P., Krawczyk M. 2017. Stratygraficzne i przestrzenne aspekty zróżnicowania składu chemicznego późnoplejstoceńskich sekwencji lessowo-glebowych w Polsce - przykłady profili w Tyszowcach i Białym Kościele. Acta Geographica Lodziensia 106: 87-103.

Starkel L. 2017. Uwagi o poligenezie rzeźby gór (na przykładzie Karpat). Acta Geographica Lodziensia 106: 31-35.

Twardy J. 2017. Holoceńska ewolucja niecek i dolin denudacyjnych w okolicach Łodzi w świetle dotychczasowych badań. Acta Geographica Lodziensia 106: 17-30.

Tylmann K., Woźniak P.P., Rinterknecht V. 2017. Analiza przydatności eratyków Pomorza w badaniach chronologii recesji ostatniego lądolodu skandynawskiego metodą izotopów kosmogenicznych. Acta Geographica Lodziensia 106: 181-194.

Winter H. 2017. Palinokompleks południowopolski jako długotrwały zapis różnoskalowych zmian klimatycznych we wczesno-środkowoplejstoceńskim przejściu (MIS 22-13). Acta Geographica Lodziensia 106: 139-154.

Pełna bibliografia prac Profesor Haliny Klatkowej znajduje się na stronie 6 .

Jacek Forysiak, Juliusz Twardy Uniwersytet Łódzki, Wydział Nauk Geograficznych, Katedra Geomorfologii i Paleogeografii, ul. Narutowicza 88, 90-139 Łódź; e-mail: jacek.forysiak@geo.uni.lodz.pl, juliusz.twardy@geo.uni.lodz.pl

DOI 10.26485/AGL/2017/106/1 